Check for updates

Cite this: RSC Adv., 2019, 9, 27937

Received 4th August 2019

Accepted 22nd August 2019

DOI: $10.1039 / c 9 r a 06046 d$

rsc.li/rsc-advances

\title{
A novel ratiometric AIEE/ESIPT probe for palladium species detection with ultra-sensitivity $\dagger$
}

\begin{abstract}
Zixuan Xu, (D) a Mingshu Zhang, ${ }^{a}$ Rui Zhang, ${ }^{a}$ Shudi Liu ${ }^{b}$ and Ying Yang (DD *a
Existing fluorescent probes for palladium (Pd) species detection have revealed their vulnerabilities, such as low sensitivity, poor anti-interference ability and long reaction time. In order to develop a faster and more accurate detection method for palladium species at extremely low concentrations, in this study, we designed a novel ratiometric AIEE/ESIPT probe (HPNI-1) based on the Tsuji-Trost reaction for Pd. According to the data obtained, the probe was able to detect Pd species with an ultra-high antiinterference ability $(\mathrm{Pd}$ : other metals $=1: 1000$ ), rapid detection time (within 2 minute) and ratiometric fluorescent signal changes with a $1.34 \mathrm{nM}$ detection limit. This study not only proves that existing methods can be improved but also provides future prospects for HPNI-1 as one of the greatest probes for Pd species detection.
\end{abstract}

\section{Introduction}

Palladium (Pd) plays a crucial role in various fields, such as functional materials, electric equipment, automobile exhaust catalysts, jewelry, and chemical transformations..$^{1-5}$ However, due to limited Pd resources and extractive technologies, the supply is not able to meet the demand, causing difficulties in actual applications. Moreover, the environmental pollution caused by the frequent use of Pd hinders the aim of sustainable development. Moreover, according to some meaningful studies, easily forming complexes between $\mathrm{Pd}$ and some biomacromolecules, such as proteins, DNA and RNA, have the possibility of causing serious health problems. ${ }^{6,7}$ The European Agency for the Evaluation of Medicinal Products (EMEA) suggested that the threshold for residual Pd is $5-10 \mathrm{ppm} .{ }^{8}$ Hence, it is critical to develop efficient methods for detecting Pd species.

Traditional detection methods for palladium species, include X-ray fluorescence, atomic absorption spectrometry (AAS), and solid phase microextraction-high performance liquid chromatography. ${ }^{\mathbf{9}, 10}$ However, these methods require expensive instruments and high-level technicians. Recently, fluorescence detection for Pd has been a focal area owing to its high sensitivity, high selectivity, simple operation and cost-effectiveness. ${ }^{11}$

Currently, fluorescent probes for palladium species detection are mainly based on coordination and catalytic

${ }^{a}$ Laboratory of Nonferrous Metals Chemistry and Resources Utilization of Gansu Province, College of Chemistry and Chemical Engineering, Lanzhou University, Lanzhou 730000, Gansu, P. R. China. E-mail: yangying@lzu.edu.cn

${ }^{b}$ College of Chemistry and Chemical Engineering, Yantai University, Yantai, 264005, P. R. China

$\dagger$ Electronic supplementary information (ESI) available: Materials and methods, synthesis, the characterization data of HPNI-1 and additional spectra. See DOI: 10.1039/c9ra06046d mechanisms. However, the majority of the coordination mechanism-based probes show poor anti-interference ability relative to other transition metal ions. ${ }^{12}$ On the contrary, probes based on a catalytic mechanism usually show superior selectivity. ${ }^{13-20}$ However, we noticed that some limitations still exist in the detection of palladium based on catalytic mechanism, such as long detection times and detection difficulty in extremely low concentrations. ${ }^{21-25}$ In addition, most fluorophores of fluorescence probes exhibit relatively small Stokes shifts, which hinders their applications in quantitative determination due to self-absorption. ${ }^{18,26-28}$ Moreover, many probes detect OFF-ON or ON-OFF signal output changes in their fluorescence intensity. This type of probe with a single fluorescence change could be significantly influenced by environmental effects, along with a decrease in signal fidelity. ${ }^{24,29,30}$ Therefore, we urgently need to develop a palladium fluorescent probe that can overcome the difficulties described above..$^{31,32}$

Thus, we present a novel ratiometric probe HPNI-1 for palladium species based on aggregated induced enhanced emission (AIEE) and excited-state intramolecular proton transfer (ESIPT) mechanisms (Fig. S2 and S3 $\dagger$ ). We specifically selected HPNI as the AIEE fluorophore, and the terminal allyl chloroformate was used as the recognition site and was modified on the hydroxyl group of HPNI to block the ESIPT process. ${ }^{33}$ After palladium treatment, the ESIPT process was recovered under ultraviolet excitation, resulting in tautomerization and a large Stokes shift $(240 \mathrm{~nm})$ (shown in Schemes 2 and 3). Moreover, we were able to get a meaningful data that showed that HPNI-1 had an ultra-fast reaction time and ultra-low detection concentration for palladium detection. Thus, we suggest that HPNI-1 is one of the best fluorescent probes of palladium species detection. 

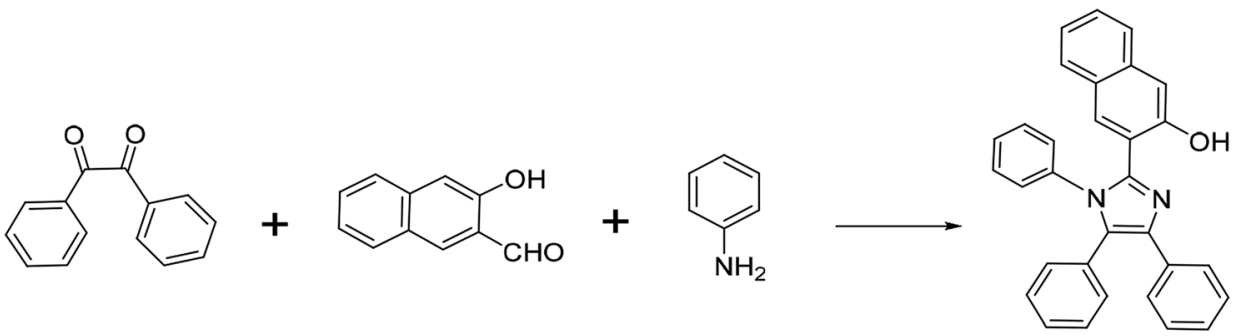

HPNI<smiles>Oc1cc2ccccc2cc1-c1nc(-c2ccccc2)c(-c2ccccc2)n1-c1ccccc1</smiles>

HPNI

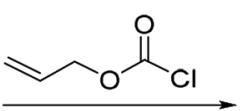

Scheme 1 Synthesis of HPNI-1.

\section{Material and methods}

\subsection{Materials and instruments}

All reagents and solvents were obtained commercially and used without further purification unless otherwise noted. ${ }^{1} \mathrm{H}$ NMR and ${ }^{13} \mathrm{C}$ NMR spectra were recorded on a JEOLBCS $400 \mathrm{M}$ spectrometer. Mass spectra (ESI) were recorded on a LQC system (Finnigan MAT, USA). All UV-visible spectra were recorded on a Varian Cary 100 spectrophotometer. Fluorescence spectra were recorded using an Edinburgh FLSP920. Fluorescence spectra were recorded after the addition of palladium for $1 \mathrm{~min}$.

\subsection{Synthesis of HPNI and HPNI-1}

Precursor HPNI was prepared according to the following procedures. $^{9}$

To a solution of HPNI (200 mg, $0.456 \mathrm{mmol}$ ) and allyl chloroformate $(0.5 \mathrm{~mL})$ in THF $(20 \mathrm{~mL})$, was added triethylamine $(0.15 \mathrm{~mL}, 1 \mathrm{mmol})$ dropwise at $0{ }^{\circ} \mathrm{C}$ for $30 \mathrm{~min}$. After that, the mixture was stirred at room temperature for $2 \mathrm{~h}$. Then, the mixture was extracted with dichloromethane, and the combined organic phase was dried over anhydrous $\mathrm{Na}_{2} \mathrm{SO}_{4}$. The solvent was removed under reduced pressure, and the residue was purified via column chromatography on silica gel with a mixture of ethyl acetate/petroleum ether $(1: 4, \mathrm{v} / \mathrm{v})$ as the eluent to obtain HPNI-1 as a yellow solid $(0.21 \mathrm{~g}, 90.3 \%) .{ }^{1} \mathrm{H}$ NMR (400 $\left.\mathrm{MHz} \mathrm{CDCl}_{3}\right) \delta 7.69(\mathrm{~d}, J=8.1 \mathrm{~Hz}, 1 \mathrm{H}), 7.65(\mathrm{~s}, 1 \mathrm{H}), 7.60(\mathrm{~s}, 1 \mathrm{H})$, $7.53(\mathrm{~d}, J=7.1 \mathrm{~Hz}, 3 \mathrm{H}), 7.37$ (ddd, $J=29.2,11.0,4.0 \mathrm{~Hz}, 2 \mathrm{H})$, 7.23-7.14 (m, 5H), 7.14-7.03 (m, 6H), 6.98 (dd, $J=8.0,1.5 \mathrm{~Hz}$, $2 \mathrm{H}$ ), 5.73 (ddt, $J=16.3,10.5,5.8 \mathrm{~Hz}, 1 \mathrm{H}$ ), 5.12 (ddd, $J=13.8$, 11.5, $1.2 \mathrm{~Hz}, 2 \mathrm{H}), 4.52$ (d, $J=5.8 \mathrm{~Hz}, 2 \mathrm{H}) .{ }^{13} \mathrm{C}$ NMR $(101 \mathrm{MHz}$, $\left.\mathrm{CDCl}_{3}\right) \delta 153.04,146.72,142.94,138.46,136.63,134.43,133.49$, $132.19,131.18,131.13,130.82$, 130.67, 130.51, 128.81, 128.42, 128.08, 128.00, 127.43, 127.30, 126.59, 126.19, 119.56, 119.21,
69.18. ESI-MS: calcd for $\left[\mathrm{C}_{35} \mathrm{H}_{26} \mathrm{~N}_{2} \mathrm{O}_{3}+\mathrm{H}^{+}\right]$, 523.2016; found, 523.2028 .

\subsection{General procedure for spectral measurements}

HPNI-1 (1 mM) was dissolved in THF and maintained at room temperature. Stock solutions of $\mathrm{Pd}\left(\mathrm{PPh}_{3}\right)_{4}, \mathrm{Pd}\left(\mathrm{PPh}_{3}\right)_{2} \mathrm{Cl}_{2}$, $\mathrm{Pd}_{2}(\mathrm{dba})_{3}$, and $\left(\mathrm{C}_{3} \mathrm{H}_{5}\right)_{2} \mathrm{PdCl}_{2}(0.1 \mathrm{mM})$ were prepared in DMSO as the sources of Pd and used freshly. $\mathrm{Zn}^{2+}, \mathrm{Ni}^{2+}, \mathrm{Na}^{2+}, \mathrm{Mn}^{2+}, \mathrm{K}^{+}$, $\mathrm{Cr}^{3+}, \mathrm{Co}^{2+}, \mathrm{Cd}^{2+}, \mathrm{Ca}^{2+}, \mathrm{Ba}^{2+}, \mathrm{NO}^{3-}, \mathrm{Cl}^{-}, \mathrm{SO}_{4}{ }^{2-}, \mathrm{CO}_{3}{ }^{2-}, \mathrm{AcO}^{-}$, $\mathrm{SCN}$, and $\mathrm{I}^{-}(10 \mathrm{mM})$ were prepared in deionized water by dissolving the corresponding salts. Test solutions were prepared by placing $20 \mu \mathrm{L}$ of HPNI-1 stock solution into a quartz cell, diluting the solution to $2 \mathrm{~mL}$ with an acetonitrile-and-water mixed solution $\left(\mathrm{CH}_{3} \mathrm{CN}: \mathrm{H}_{2} \mathrm{O}=3: 2, \mathrm{KBH}_{4}=1 \mathrm{mM}\right)$, and then different analytes were added. All of the UV-vis absorption and fluorescence measurements were taken at room temperature. The selected excitation and emission wavelengths were at

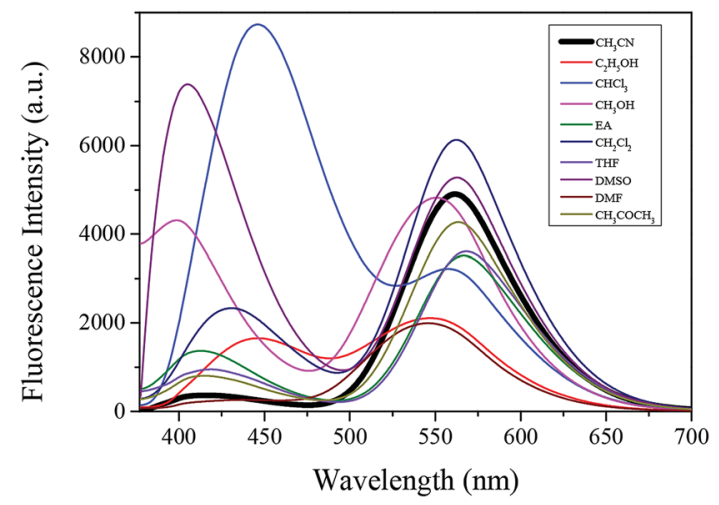

Fig. 1 Emission spectra of HPNI in different solutions. Concentration $10 \mu \mathrm{M}, \lambda_{\mathrm{ex}}=365 \mathrm{~nm}$. 

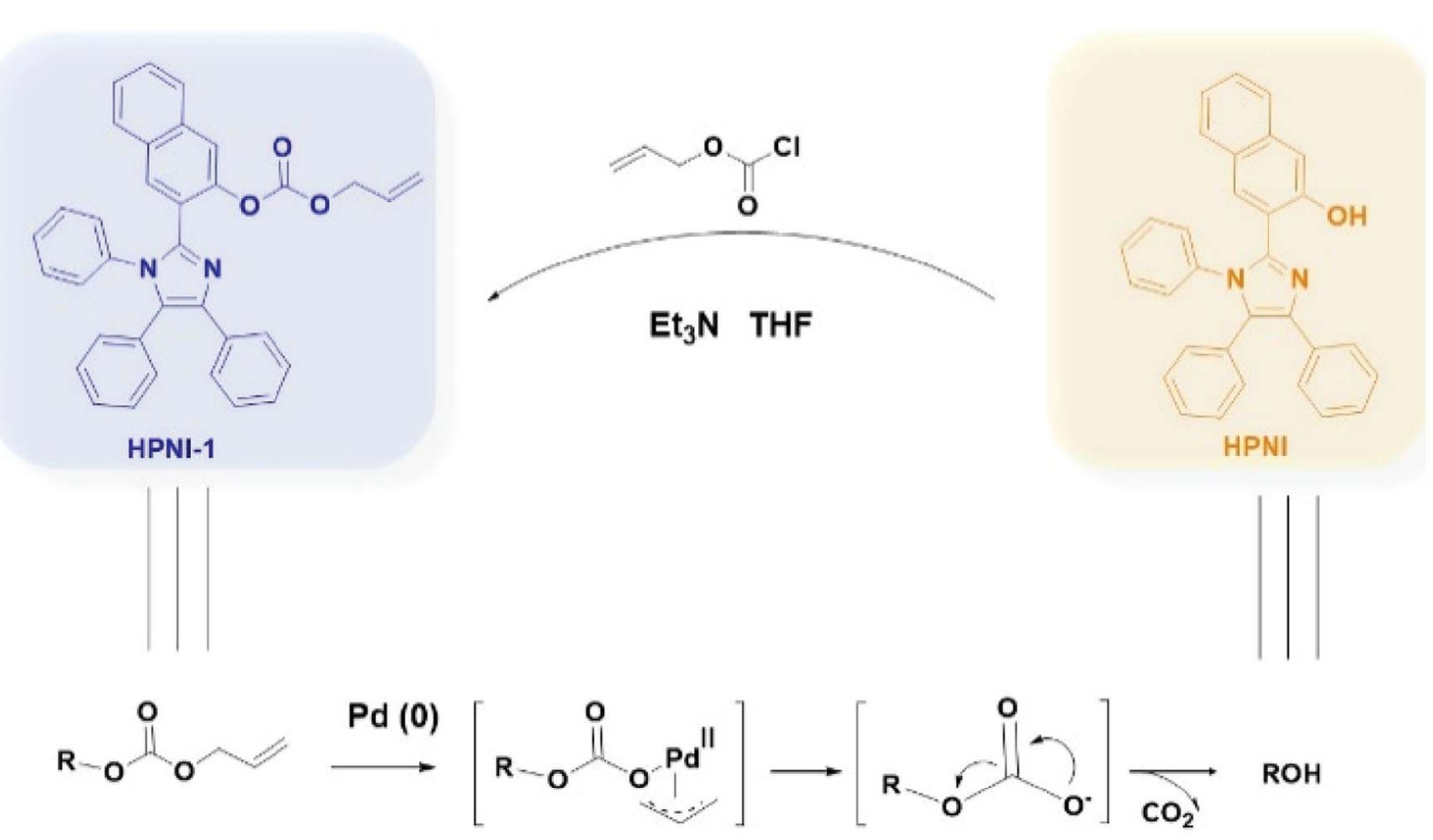

Scheme 2 The sensing mechanism of HPNI-1 for the selective recognition of palladium.

$365 \mathrm{~nm}$ and $570 \mathrm{~nm}$, respectively. The excitation slit width was $5 \mathrm{~nm}$, and emission slit width was $5 \mathrm{~nm}$. The fluorescence spectra were recorded after 2 min after the addition of analytes into the quartz cell to allow the complete mixing of the analytes into the solution.

\subsection{Determination of the detection limit}

According to the fluorescence titration, the fluorescence intensity ratio $\left(I_{570} / I_{410}\right)$ and the concentration of $\operatorname{Pd}(0)(0-50 \mathrm{nM})$ showed an excellent linear relationship. The detection limit was calculated by the following equation:

$$
\text { Detection limit }=3 \sigma / k
$$

where $\sigma$ is the standard deviation of the blank sample (measured 10 times) and $k$ is the slope of the linear regression equation.

\section{Results and discussion}

The synthetic process of the probe HPNI-1 is shown in Scheme 1. We chose HPNI as the fluorophore due to its large Stokes shift $(240 \mathrm{~nm})$ by the excited-state intramolecular proton transfer (ESIPT) process. This fluorophore also has a high fluorescence quantum yield $(\Phi=0.22)$. Terminal allyl chloroformate was used as the recognition site, which was modified on the hydroxyl group of HPNI to block the ESIPT process. HPNI-1 was characterized by ${ }^{1} \mathrm{H}$ NMR, ${ }^{13} \mathrm{C}$ NMR and HR-MS.

\subsection{The fluorescence spectrum of HPNI in various solutions}

The emission spectra of HPNI in different solutions are shown in Fig. 1. We noticed that HPNI has dual emission bands, which can be attributed to the coexistence of two tautomers in the ESIPT process (Scheme 3). We suggest that the shorter emission bands are ascribed to the enol form of HPNI. Relatively, the

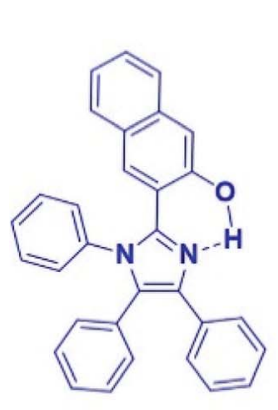

E-HPNI

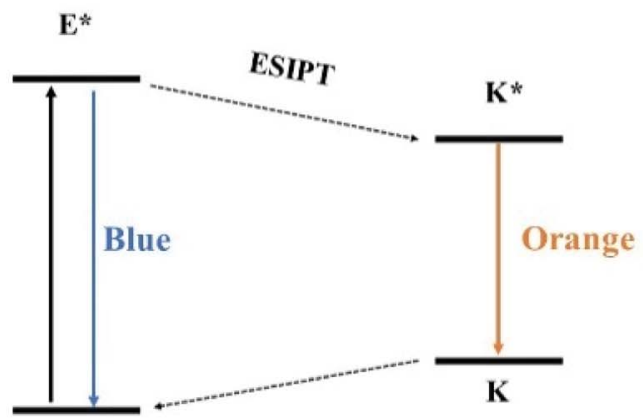

$\mathbf{E}$

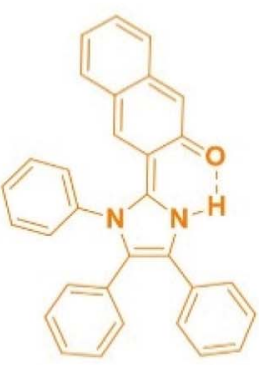

K-HPNI

Scheme 3 General mechanism of ESIPT process and chemical structures of enol form (E) and keto from (K) in the ESIPT process of HPNI. 

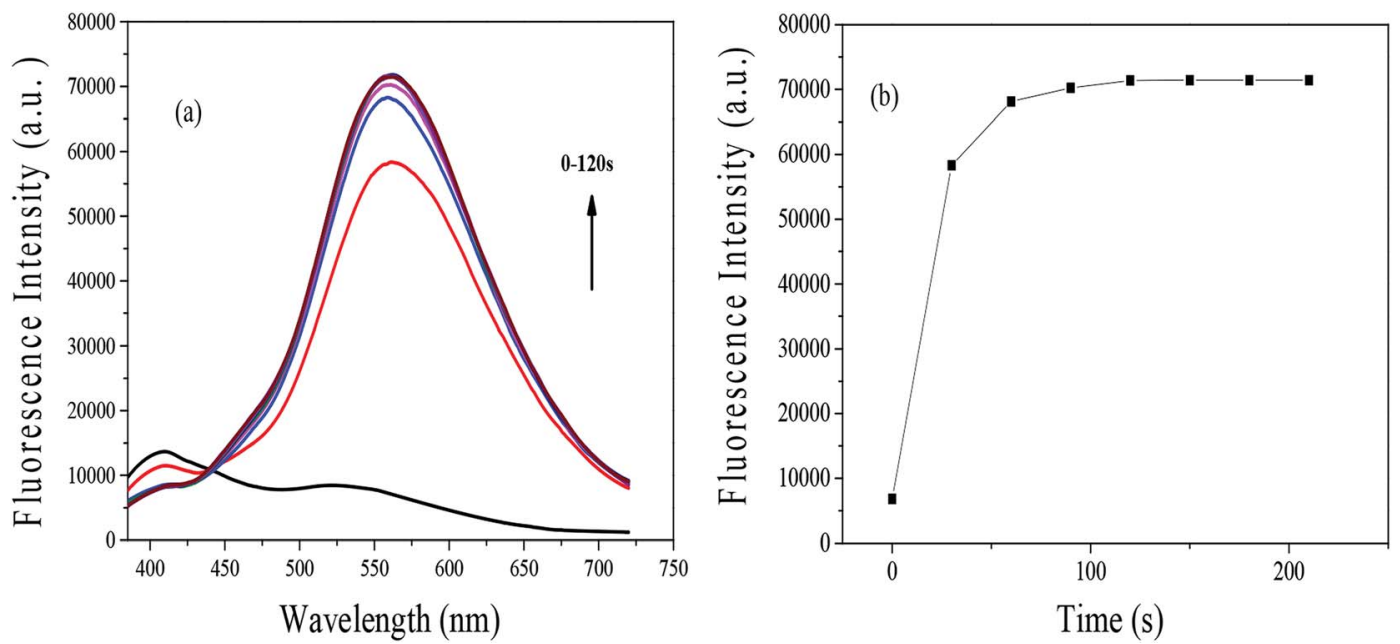

Fig. 2 (a) Fluorescence spectral changes of HPNI-1 $(10 \mu \mathrm{M})$ and (b) the relationship between fluorescence intensity and reaction time upon treatment with $\mathrm{Pd}\left(\mathrm{PPh}_{3}\right)_{4}(2 \mu \mathrm{M})$ in acetonitrile-water solution $\left(\mathrm{CH}_{3} \mathrm{CN}: \mathrm{H}_{2} \mathrm{O}=3: 2, \mathrm{KBH}_{4}(1 \mathrm{mmol})\right) \mathrm{Ex}=365 \mathrm{~nm}$.

longer emission band can be assigned to the keto form of HPNI. HPNI exhibits strong fluorescence emission at $570 \mathrm{~nm}$ and extremely weak fluorescence emission at $410 \mathrm{~nm}$ in acetonitrile, indicating that the keto form is the main form of HPNI in acetonitrile. Therefore, choosing acetonitrile as the solvent makes detection more reliable. In addition, in the mixed solution of $\mathrm{CH}_{3} \mathrm{CN}$ and $\mathrm{H}_{2} \mathrm{O}$ at various ratios, HPNI and HPNI-1 had relatively high fluorescence intensities when $\mathrm{CH}_{3} \mathrm{CN}: \mathrm{H}_{2} \mathrm{O}=$ $3: 2$ (Fig. S1 and S2 $\dagger$ ). Therefore, we chose $\mathrm{CH}_{3} \mathrm{CN}: \mathrm{H}_{2} \mathrm{O}=3: 2$ mixed solutions as a solvent.

\subsection{Fluorescence response toward $\operatorname{Pd}(0)$}

The fluorescence spectra of HPNI-1 $\left(\mathrm{CH}_{3} \mathrm{CN}: \mathrm{H}_{2} \mathrm{O}=3: 2\right.$, $\mathrm{KBH}_{4}: 1 \mathrm{mmol}$ ) at room temperature was investigated (Fig. 2), and HPNI-1 showed fluorescence emission at $410 \mathrm{~nm}$ upon excitation at $365 \mathrm{~nm}$. After reaction with palladium, a decrease in the emission intensity at $410 \mathrm{~nm}$ was observed. Moreover, a new emission band appeared at $570 \mathrm{~nm}$, which created an isosbestic point at $460 \mathrm{~nm}$ that exhibited a ratiometric response. The large red-shift $(160 \mathrm{~nm})$ is due to the ESIPT process being recovered. Notably, the fluorescence intensity reached equilibrium within $2 \mathrm{~min}$.

\subsection{The sensitivity}

Fig. 3a shows the fluorescence changes with various amounts of $\mathrm{Pd}\left(\mathrm{PPh}_{3}\right)_{4}$ in a $\mathrm{CH}_{3} \mathrm{CN}: \mathrm{H}_{2} \mathrm{O}(3: 2 \mathrm{v} / \mathrm{v})$ solution with $\mathrm{KBH}_{4}(1$ $\mathrm{mM})$ after $2 \mathrm{~min}$. When the concentration of $\mathrm{Pd}\left(\mathrm{PPh}_{3}\right)_{4}$ gradually increases, the fluorescence peak at $\lambda=410 \mathrm{~nm}$ shows a slow decrease, and a new fluorescence peak appears at $\lambda=570 \mathrm{~nm}$ and then becomes the maximum peak. The ratio of the fluorescence intensities $\left(\lambda_{570} / \lambda_{410}\right)$ changes from 0.18 to $5.34(R=$ 30.24-fold). More importantly, as the concentration of $\mathrm{Pd}\left(\mathrm{PPh}_{3}\right)_{4}$ increases from 0 to $500 \mathrm{nM}$, the ratio of the fluorescent intensity shows an excellent linear relationship.
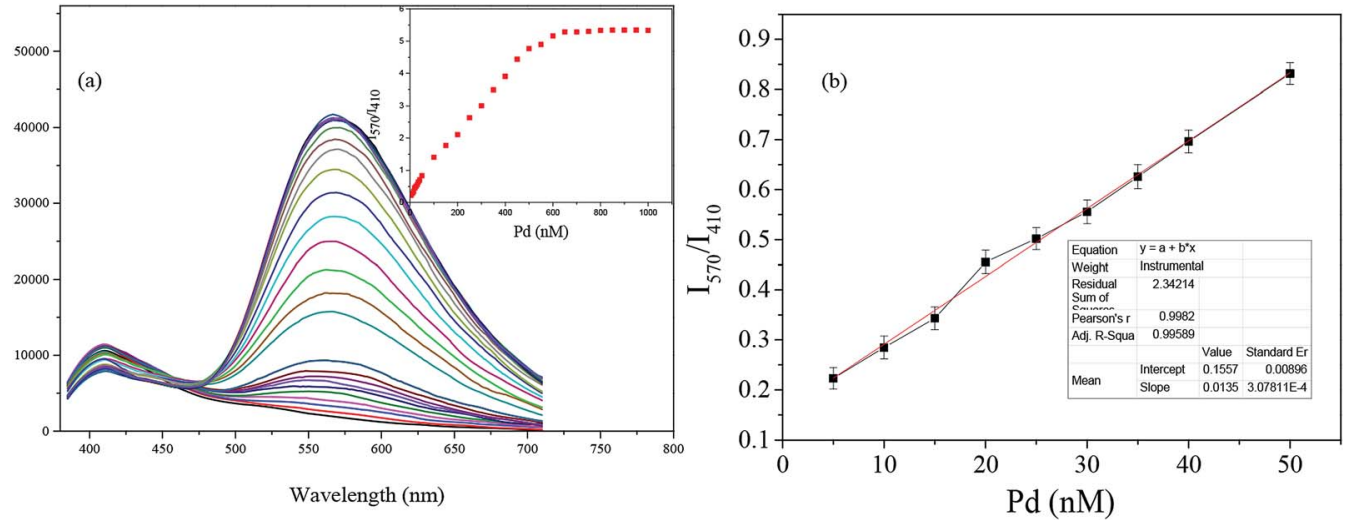

Fig. 3 (a) Fluorescent spectral changes of HPNI-1 $(10 \mu \mathrm{M})$ upon addition of different concentrations of $\mathrm{Pd}\left(\mathrm{PPh}_{3}\right)_{4}(0-1 \mu \mathrm{M})$ in acetonitrile-water solutions $\left(\mathrm{CH}_{3} \mathrm{CN}: \mathrm{H}_{2} \mathrm{O}=3: 2, \mathrm{KBH}_{4}: 1 \mathrm{mM}\right)$ at room temperature. Each spectrum was obtained $2 \mathrm{~min}$ after $\mathrm{Pd}\left(\mathrm{PPh}_{3}\right)_{4}$ addition. Ex $=365 \mathrm{~nm}$. Slit: $5.0 \mathrm{~nm} / 5.0 \mathrm{~nm}$. Inset: The fluorescent intensity ratio changes at 570 and $410 \mathrm{~nm}\left(/_{570} / /_{410}\right)$ against the concentrations of Pd(PPh $)_{4}$. (b) Linear relationship of the $I_{570} / I_{410}$ as a function of the concentration of $\mathrm{Pd}\left(\mathrm{PPh}_{3}\right)_{4}$ from 5 to $50 \mathrm{nM}$. 

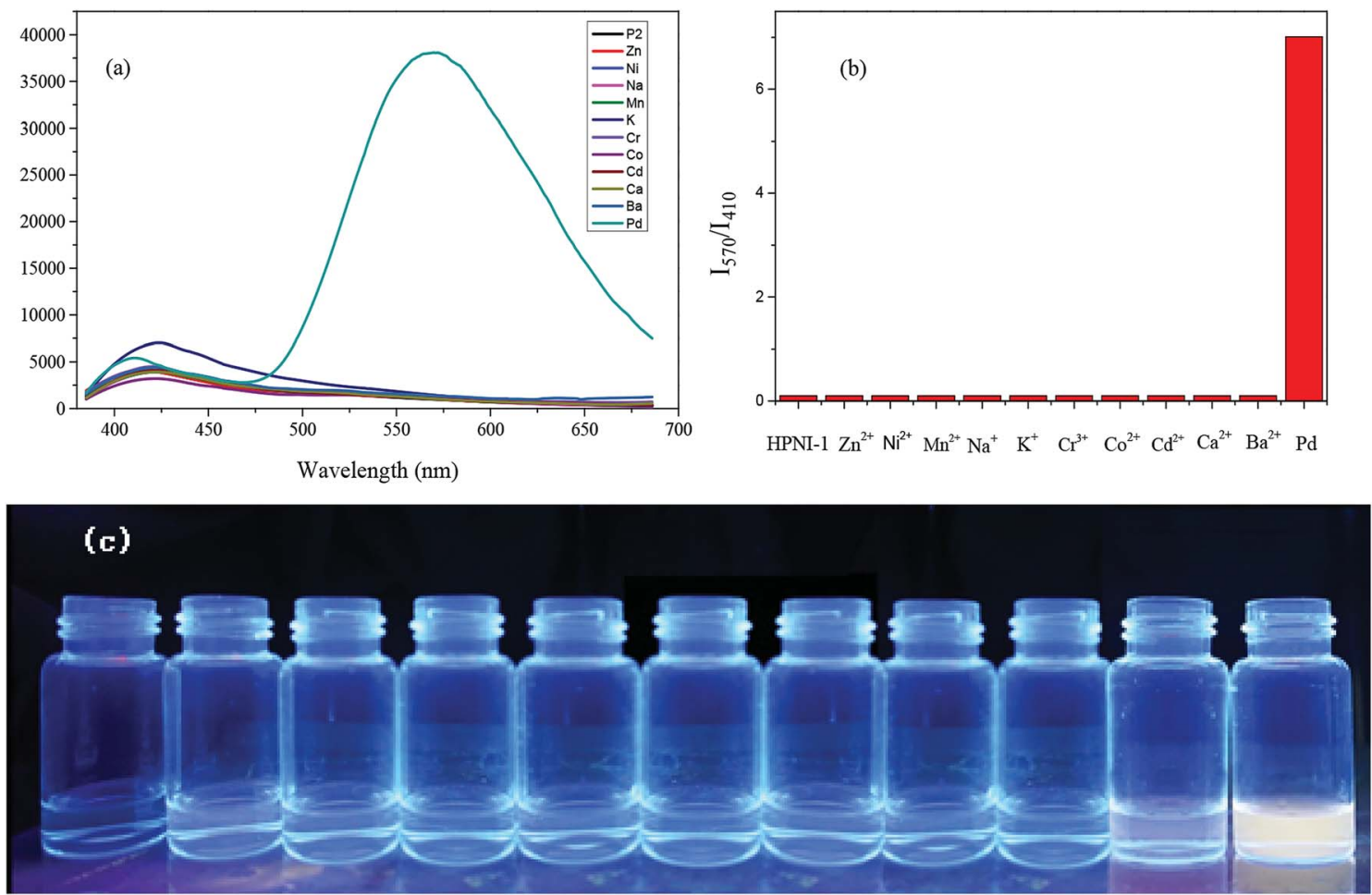

Fig. 4 (a) Fluorescent spectral (b) fluorescence intensity and (c) photograph of $\mathrm{HPNI}-1(10 \mu \mathrm{M})$ with the addition of $\mathrm{Pd}(\mathrm{PPh})_{4}(1 \mu \mathrm{M})$ and other metal ions $(1 \mathrm{mM})$ in acetonitrile-water solutions $\left(\mathrm{CH}_{3} \mathrm{CN}: \mathrm{H}_{2} \mathrm{O}=3: 2, \mathrm{KBH}_{4}: 1 \mathrm{mM}\right)$ at room temperature. Each spectrum was obtained 2 min after the metal ion addition. Ex $=365 \mathrm{~nm}$. Slit: $5.0 \mathrm{~nm} / 5.0 \mathrm{~nm}$.

The ratiometric fluorescent detection method is based on the ratio of the two fluorescent bands rather than the absolute emission intensity of one band, making it possible to analyze palladium species more accurately and sensitively by minimizing the background signal. Moreover, under the ultra-low concentrations of $\operatorname{Pd}\left(\mathrm{PPh}_{3}\right)_{4}$, the good linear relationship is maintained (Fig. 3b). According to the data presented in the research and eqn (1), the detection limit of HPNI-1 for $\operatorname{Pd}(0)$ is $1.34 \mathrm{nM}$. (The sensitivity of HPNI-1 was far beyond those of other reported studies and much lower than the palladium content in the samples of human saliva $\left.\left(7.4 \mu \mathrm{g} \mathrm{L} \mathrm{L}^{-1}\right)\right)$. That is,
HPNI-1 can serve as a sensitive ratiometric fluorescent sensor for the quantitative detection of Pd.

\subsection{The sensitivity}

Selectivity experiments were performed with different metal ions (Fig. 4). In the mixed solution $\left(\mathrm{CH}_{3} \mathrm{CN}: \mathrm{H}_{2} \mathrm{O}=3: 2, \mathrm{KBH}_{4}\right.$ $=1 \mathrm{mM})$, the ratiometric response can only be detected when $\operatorname{Pd}(0)(1 \mu \mathrm{M})$ is added to the solution. Other metals such as $\mathrm{Zn}^{2+}$, $\mathrm{Ni}^{2+}, \mathrm{Na}^{2+}, \mathrm{Mn}^{2+}, \mathrm{K}^{+}, \mathrm{Cr}^{3+}, \mathrm{Co}^{2+}, \mathrm{Cd}^{2+}, \mathrm{Ca}^{2+}$ and $\mathrm{Ba}^{2+}(1 \mathrm{mM})$ have no or an insignificant influence on the detection. Under UV light (365 nm), significant orange fluorescence is observed. The
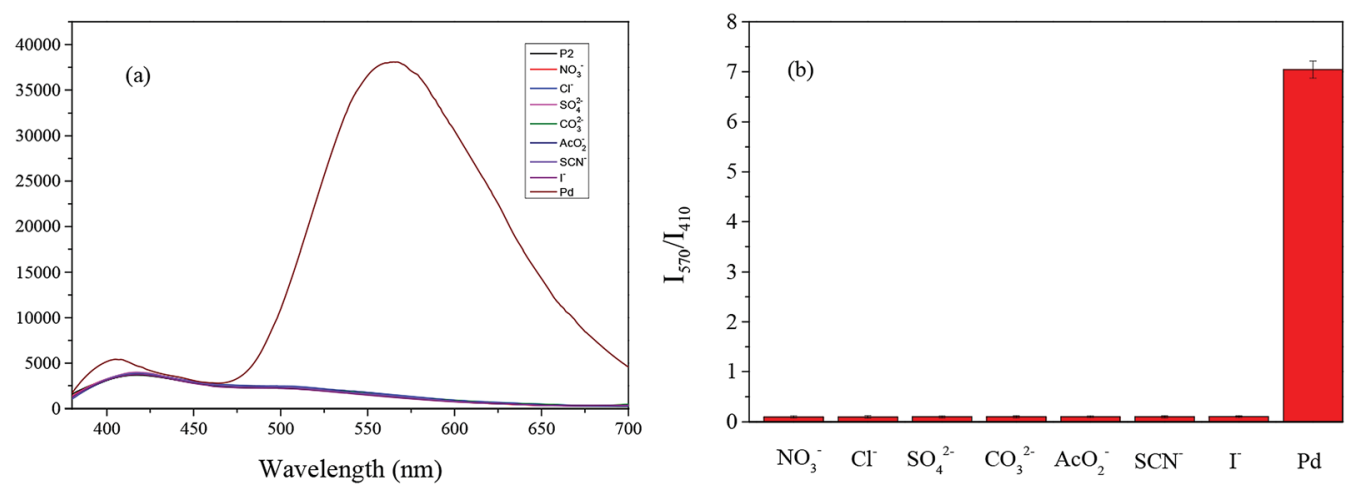

Fig. 5 (a) Fluorescence spectra and (b) fluorescence intensity of HPNI-1 $(10 \mu \mathrm{M})$ with the addition of $\mathrm{Pd}(\mathrm{PPh})_{4}(1 \mu \mathrm{M})$ and other anions $(1 \mathrm{mM})$ in acetonitrile-water solutions $\left(\mathrm{CH}_{3} \mathrm{CN}: \mathrm{H}_{2} \mathrm{O}=3: 2, \mathrm{KBH}_{4}: 1 \mathrm{mM}\right)$ at room temperature. Each spectrum was obtained 2 min after metal ion addition. Ex $=365 \mathrm{~nm}$. Slit: $5.0 \mathrm{~nm} / 5.0 \mathrm{~nm}$. 

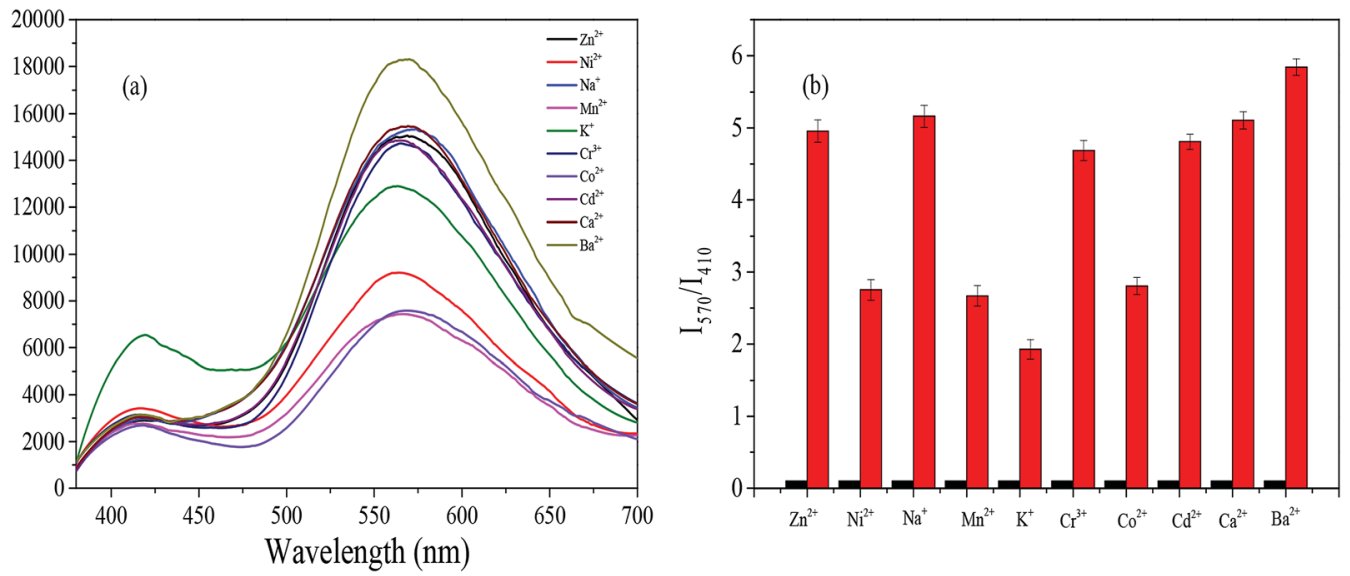

Fig. 6 (a) Fluorescence detection and (b) fluorescence intensity ratio $\left(/ 570 / /_{410}\right)$ of $\mathrm{Pd}\left(\mathrm{PPh}_{3}\right)_{4}(0.3 \mu \mathrm{M})$ with $\mathrm{HPNI}-1$ (10 $\left.\mu \mathrm{M}\right)$ in the presence of other metal ions $(0.3 \mathrm{mM})$ in acetonitrile-water solutions $\left(\mathrm{CH}_{3} \mathrm{CN}: \mathrm{H}_{2} \mathrm{O}=3: 2, \mathrm{KBH}_{4}: 1 \mathrm{mM}\right)$ at room temperature. Each spectrum was obtained 2 min after metal ion addition. $\mathrm{Ex}=365 \mathrm{~nm}$. Slit: $5.0 \mathrm{~nm} / 5.0 \mathrm{~nm}$.

experimental results of the interference of the above-mentioned metal ions on $\operatorname{Pd}(0)$ show that HPNI-1 possesses ultra-high selectivity for palladium detection. $\left([\operatorname{Pd}(0)] /\left[\mathrm{M}^{n+}\right]=1: 1000\right)$.

Similarly, we conducted selectivity and anti-interference experiments on the anions $\left(\mathrm{NO}^{3-}, \mathrm{Cl}^{-}, \mathrm{SO}_{4}{ }^{2-}, \mathrm{CO}_{3}{ }^{2-}, \mathrm{AcO}^{-}\right.$, SCN, and $\mathrm{I}^{-}$) (Fig. 5), and HPNI-1 again showed excellent selectivity for the palladium species.

\subsection{The anti-interference ability}

We also investigated the anti-interference ability of HPNI-1; as shown in Fig. 6, we can observe the fluorescence responses for $\operatorname{Pd}(0)$ detection at high concentrations of the metal ion solutions (metal ions : $\operatorname{Pd}\left(\mathrm{PPh}_{3}\right)_{4}=1000: 1$ ). Due to its ultra-high anti-interference characteristic, HPNI-1 possesses a great practical application value for $\operatorname{Pd}(0)$ detection.

\subsection{The sensing behavior of HPNI-1 for other palladium sources}

To verify the potential application of HPNI-1, we tested whether the probe could detect all the oxidation states of $\mathrm{Pd}$ $\left[\operatorname{Pd}(0): \operatorname{Pd}\left(\mathrm{PPh}_{3}\right)_{4}, \quad \mathrm{Pd}_{2}(\mathrm{dba})_{3} ; \quad \operatorname{Pd}(\mathrm{II}): \mathrm{PdCl}_{2}\left(\mathrm{PPh}_{3}\right)_{2}\right.$, $\left.\left(\mathrm{C}_{3} \mathrm{H}_{5}\right)_{2} \mathrm{PdCl}_{2} ; \mathrm{Pd}(\mathrm{Iv}): \mathrm{K}_{2} \mathrm{PdCl}_{6}\right]$. According to the intensity ratio $\left(I_{570} / I_{410}\right)$, the sensitivity of HPNI-1 to palladium was $\operatorname{PdCl}_{2}(-$ $\left.\mathrm{PPh}_{3}\right)_{2}>\mathrm{Pd}\left(\mathrm{PPh}_{3}\right)_{4}>\mathrm{Pd}_{2}(\mathrm{dba})_{3}>\left(\mathrm{C}_{3} \mathrm{H}_{5}\right)_{2} \mathrm{PdCl}_{2}>\mathrm{K}_{2} \mathrm{PdCl}_{6}$, as shown in Fig. 7. The results showed that HPNI-1 has a significant response to all the oxidation states of palladium, and the fluorescence changed significantly. In addition, we noticed that in the detection of palladium complexes, containing organic ligands had relatively stronger fluorescence intensities.

To deeply investigate the reaction mechanism of HPNI-1 and $\mathrm{Pd}\left(\mathrm{PPh}_{3}\right)_{4},{ }^{1} \mathrm{H}$ NMR titration experiment was performed in

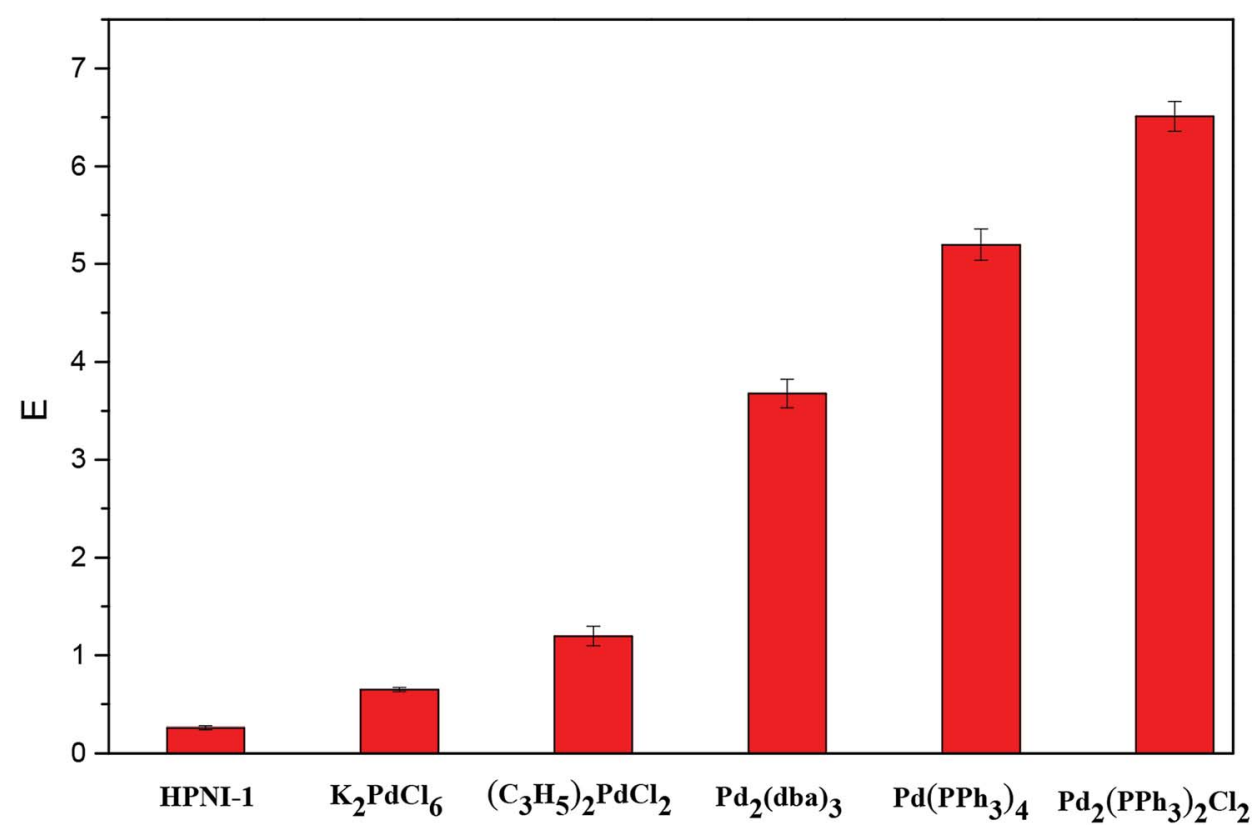

Fig. 7 The fluorescence responses of HPNI-1 $(10 \mu \mathrm{M})$ to various palladium sources $(1 \mu \mathrm{M}) .\left(\mathrm{CH}_{3} \mathrm{CN}: \mathrm{H}_{2} \mathrm{O}=3: 2, \mathrm{KBH}_{4}: 1 \mathrm{mM}\right)$. 
(a)

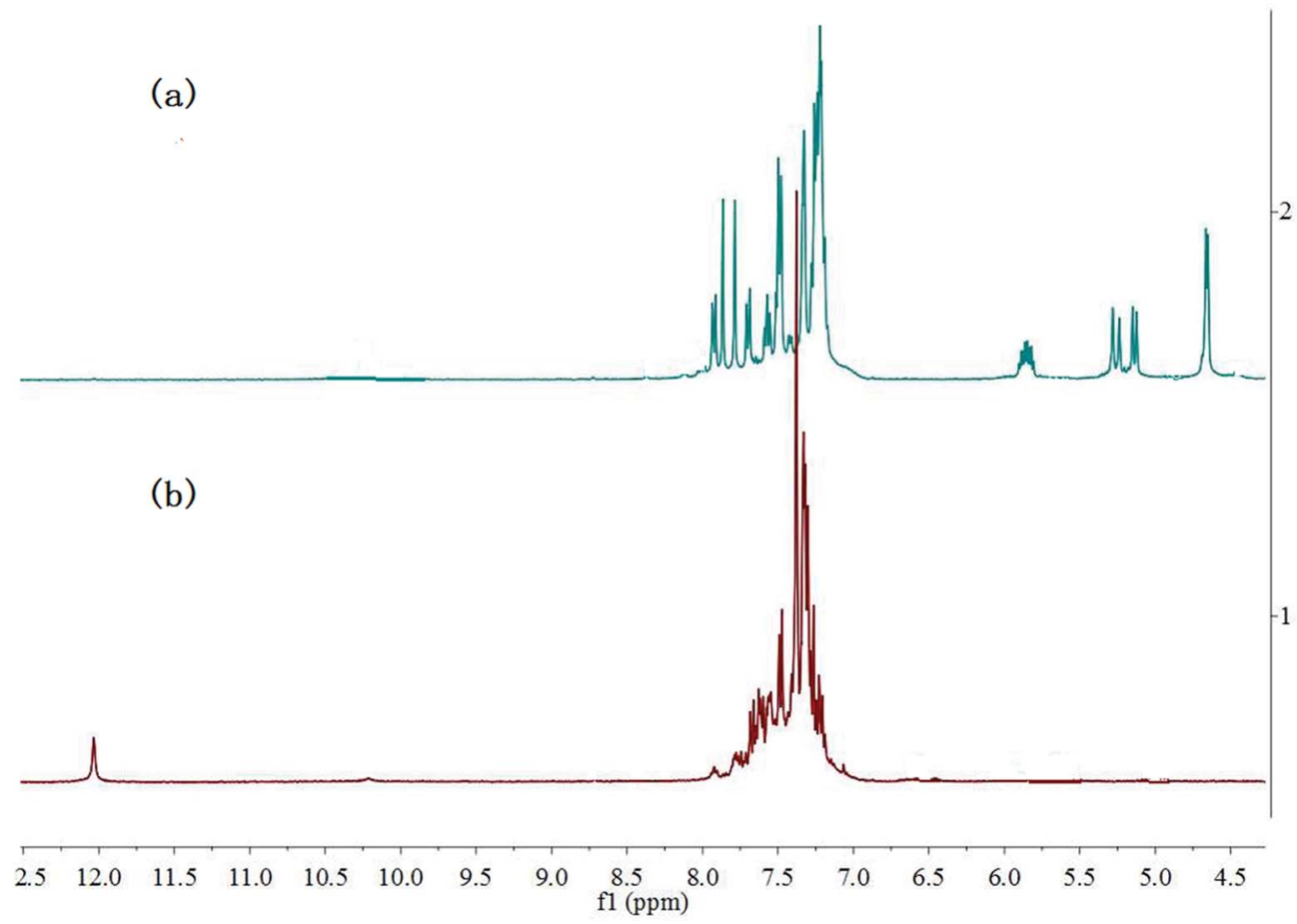

Fig. 8 Stacked ${ }^{1} \mathrm{H}$ NMR spectra of (a) HPNI-1 and (b) upon addition of $\mathrm{Pd}\left(\mathrm{PPh}_{3}\right)_{4}$ in DMSO- $d_{6}$.

DMSO- $d_{6}$ (Fig. 8). For HPNI-1, the multiple peaks between 5.75 and 5.93 ppm and the doublet peaks appearing at 5.28 and 5.15 ppm were assigned to the $\mathrm{CH}=$ and $=\mathrm{CH}_{2}$ protons in the allyl group, respectively (Fig. 8a). These characteristic peaks disappeared in the ${ }^{1} \mathrm{H}$ NMR spectrum after $\operatorname{Pd}\left(\mathrm{PPh}_{3}\right)_{4}$, treatment (0.1 equiv.) (Fig. $8 \mathrm{~b})$. Moreover, a new peak attributed to the $\mathrm{OH}$ group in HPNI appeared at $12.03 \mathrm{ppm}$. It is clear that the ${ }^{1} \mathrm{H}$ NMR spectrum is almost identical to that of standard HPNI, ${ }^{33}$ demonstrating that the reaction of HPNI-1 with $\mathrm{Pd}^{0}$ results in the release of $\mathrm{HPNI}-\mathrm{OH}$. Based on these results and some previous reports, the mechanism of HPNI-1 for $\mathrm{Pd}^{0}$ detection is illustrated in Scheme 2.

\section{Conclusion}

In conclusion, we successfully synthesized a novel fluorescence probe (HPNI-1) for palladium species detection based on a Pd(0)-triggered cleavage reaction. HPNI-1 possessed ultra-high selectivity and anti-interference ability. Moreover, HPNI-1 exhibited obvious ratiometric fluorescence responses toward palladium due to the ESIPT process, with a color change from weak blue to strong orange. Moreover, the probe had an astonishing detection limit $(1.34 \mathrm{nM})$, which has far exceeds those of other reported probes. Thus, we suggest that HPNI-1 has great potential to detect ultra-low concentrations of palladium species in environmental settings.

\section{Conflicts of interest}

The authors declare no competing financial interest.

\section{Acknowledgements}

This work was supported by the National Natural Science Foundation of China (Grant 51474118, 21701074).

\section{References}

1 SESSION, DWHORATR International Programme on Chemical Safety, 2009.

2 R. Martin and S. L. Buchwald, Acc. Chem. Res., 2008, 41, 1461-1473.

3 W. Wu and H. Jiang, Acc. Chem. Res., 2012, 45, 1736-1748.

4 S.-Y. Ding, J. Gao, Q. Wang, Y. Zhang, W.-G. Song, C.-Y. Su and W. Wang, J. Am. Chem. Soc., 2011, 133, 19816-19822.

5 Z. He, B. Dong, W. Wang, G. Yang, Y. Cao, H. Wang, Y. Yang, Q. Wang, F. Peng and H. Yu, ACS Catal., 2019, 9, 2893-2901.

6 J. Wataha and C. Hanks, J. Oral Rehabil., 1996, 23, 309-320.

7 J. Kielhorn, C. Melber, D. Keller and I. Mangelsdorf, Int. J. Hyg. Environ. Health, 2002, 205, 417-432.

8 C. E. Garrett and K. Prasad, Adv. Synth. Catal., 2004, 346, 889-900.

9 K. Van Meel, A. Smekens, M. Behets, P. Kazandjian and R. Van Grieken, Anal. Chem., 2007, 79, 6383-6389.

10 C. Locatelli, D. Melucci and G. Torsi, Anal. Bioanal. Chem., 2005, 382, 1567-1573.

11 H. Li, J. Fan and X. Peng, Chem. Soc. Rev., 2013, 42, 79437962.

12 M. N. Yaraşir, M. Kandaz, A. Koca and B. Salih, Polyhedron, 2007, 26, 1139-1147.

13 J. Jiang, H. Jiang, W. Liu, X. Tang, X. Zhou, W. Liu and R. Liu, Org. Lett., 2011, 13, 4922-4925. 
14 M. Santra, S.-K. Ko, I. Shin and K. H. Ahn, Chem. Commun., 2010, 46, 3964-3966.

15 B. Liu, H. Wang, T. Wang, Y. Bao, F. Du, J. Tian, Q. Li and R. Bai, Chem. Commun., 2012, 48, 2867-2869.

16 R. M. Yusop, A. Unciti-Broceta, E. M. Johansson, R. M. Sánchez-Martín and M. Bradley, Nat. Chem., 2011, 3, 239.

17 Q. Xia, S. Feng, D. Liu and G. Feng, Sens. Actuators, B, 2018, 258, 98-104.

18 W. Feng, L. Bai, S. Jia and G. Feng, Sens. Actuators, B, 2018, 260, 554-562.

19 X. Jie, M. Liu, A. Peng, J. Huang, Y. Zhang, X. Wang and Z. Tian, Talanta, 2018, 183, 164-171.

20 J. Zhou, S. Xu, Z. Yu, X. Ye, X. Dong and W. Zhao, Dyes Pigm., 2019, 170, 107656.

21 W. Luo, J. Li and W. Liu, Org. Biomol. Chem., 2017, 15, 58465850.

22 B. Zhu, C. Gao, Y. Zhao, C. Liu, Y. Li, Q. Wei, Z. Ma, B. Du and X. Zhang, Chem. Commun., 2011, 47, 8656-8658.

23 H. Chen, W. Lin and L. Yuan, Org. Biomol. Chem., 2013, 11, 1938-1941.
24 J.-w. Yan, X.-l. Wang, Q.-f. Tan, P.-f. Yao, J.-h. Tan and L. Zhang, Analyst, 2016, 141, 2376-2379.

25 T. Gao, P. Xu, M. Liu, A. Bi, P. Hu, B. Ye, W. Wang and W. Zeng, Chem.-Asian J., 2015, 10, 1142-1145.

26 X. Teng, M. Tian, J. Zhang, L. Tang and J. Xin, Tetrahedron Lett., 2018, 59, 2804-2808.

27 H. Nie, J. Geng, J. Jing, Y. Li, W. Yang and X. Zhang, RSC Adv., 2015, 5, 97121-97126.

28 W. Luo and W. Liu, Dalton Trans., 2016, 45, 11682-11687.

29 M. Liu, T. Leng, K. Wang, Y. Shen and C. Wang, J. Photochem. Photobiol., A, 2017, 337, 25-32.

30 W. Su, B. Gu, X. Hu, X. Duan, Y. Zhang, H. Li and S. Yao, Dyes Pigm., 2017, 137, 293-298.

31 L. Zhou, Q. Wang, X.-B. Zhang and W. Tan, Anal. Chem., 2015, 87, 4503-4507.

32 L. Zhou, S. Hu, H. Wang, H. Sun and X. Zhang, Spectrochim. Acta, Part A, 2016, 166, 25-30.

33 S. Park, J. E. Kwon, S. H. Kim, J. Seo, K. Chung, S.-Y. Park, D.-J. Jang, B. M. Medina, J. Gierschner and S. Y. Park, J. Am. Chem. Soc., 2009, 131, 14043-14049. 